\title{
EVALUATION OF SOME LOCAL INSECTICIDES AND THIER ALTERNATIVES AGAINST (Scymnus Syriacus MARS).
}

\author{
E.M.S. Hassan; H.H. A.Hashem; W.G T.Ghatwary and W.M.H. Desuky \\ Plant Protection Research Institute, Agricultural Research Center, Egypt.
}

\begin{abstract}
The extremely hazardous effects of the local insecticidal alternatives namely; mineral oil CAPL-2; organic acid; i.e. citric acid as well as biocides included profect evaluated against the predaceous insect; Scymnus syriacus Mars. Stages (egg, Larvae, pupae and adult) in comparable with the conventional insecticide; Nuvacron. Four Experiments were carried out for determination the hazardous effects of insecticidal alternatives and Navacron by using their recommend rates for controlling either aphid/firstly for determination of their ovicidal effect secondly, determination of their toxic effect on the larval stage, the third one for determination their efficacy against pupae and the fourth experiment was aimed to determine their toxic effect on the adult stage. Two methods were used for the evaluation the type stage of the natural enemy, where in case of non-feeding stages included egg and pupae were exposed directly spraying with recommend rats of the components used for those stages. Concerning feeding stages; i.e. larvae and adult was introduced to the leaves were sprayed with the recommended rates of the tested materials forementioned previously. The obtained results indicated that the conventional insecticide ie. Nuvacron was the most most hazarvdous treatment against all stages of the predaceus insect Scymnus syriacus Mars. While the citric acid was the most safe component followed by the tested biocide; as well as CAPL-2. It could be concluded that the insecticidal alternatives should be used in the IPM programs for controlling the cotton aphids in the objective of keeping the natural enemies to do their effects as control agent.
\end{abstract}

Keywords: Local insecticides, alternatives, Scymnus syriacus Mars).

\section{INTTRODUCTIN}

Vegetable crops are considered one of the important crops in Egypt. The importance of vegetable crops as food lies in their high protein contents. In the field, plants are infested with many pierceing sucking pests such as aphid and whitefly which cause great damage to the plants and loss in the yield (Ahmed, 1995 and Barlett ,1964). Application of the conventional insecticides for controlling these pests infesting watermelon cause unexpected side effects such as: pollute the environment, pest resistance, pest resurgence, outbreak of secondary pests and their toxic effect aginst natural enemies such as predators. These harmful consequence have induced a need for alternative control methods (El-Hariry et al., 1998). 
The aims of the following research is to study the toxic efficacy of the insecticidal alternatives namely; (Capl-2, citric acid, and profect) in comparable with the insecticide nuvacron against the predaceous insect Scymus syriacus.

\section{MATERIALS AND METHODS}

\section{Compounds used}

- CAPL-2: Amedium cut of petroleum oil, prepared as emulsifiable by petroleum Egypt.

- Citric acid: Supplied by El-Gomhoria Co. for chemicals, Zagazig in Egypt.

-Profect: It is (NPV) prepared as wettable powder used at $300 \mathrm{~g} /$ feddan Biocide were Produced by plant protection research Institute.

Hazard effects of the condidate alternative compared with conventional insecticide used against aphid nuvacron were conducted against Scymnus syriacus stages at their recommended rate against aphid as the following:

1- Effect of the egg stages of Scymnus syriacus: The test was carried out (Topper et al., 1984 and Zhao et al.,1995) with some modification in Egypt. S. syricus laid on black crepe were directly sprayed with tested alternatives, and nuvacron at their recommended concentration compared with control sprayed with water alone, the papers were then hung until dry then placed in petri-dishes, five crepe sheets each have 20 eggs were used for each treatment. Hatched and unhatched eggs were counted up to 7 days of treatment, then $\%$ hatchability was calculated.

2- Effect of the larval $S$. Syriacus indirect spray method used in this case. The experiment was carried on leaves of the watermelon that were collected from the field then sprayed with tested alternatives at their recommended concentration. They were brushed from only one leave into each untreated plastic cup where each larvae of the predator was fed for $24 \mathrm{hrs}$ on the treated cotton aphids. Control. Experiments conducted by feeding the larvae were counted daily up to 10 days post treatment. Mortality percentages were calcultated for each treatment and compared with untreated one according to Mousa and El-Sisi (2000).

3- Effect of the pupal stage of S. Syriacus: Each treatment was directly sprayed similar to the egg stage. Five replicates in each have 20 pupal stage in petri-dish, after drying were closed with cover. The emerged and unemerged pupae were counted up to 7 days of treatment. The emergency percentage calcutated.

4- Effect of the adult S. Syriacus indirect spray method used in this case. The experiment was carried out on leaves of the watermelon collected from the field then sprayed with tested alternatives at their recommended concentration. They were brushed from only one leave into each untreated plastic cup where each adult of the predator was fed for $24 \mathrm{hrs}$ on the treated cotton aphids. Control experiments were conducted by feeding the adult were counted daily up to 10 days post treatment. Mortality percentages were calculated for each treatment and compared with untreated. 


\section{RESULTS AND DISCUSSION}

1-The ovicidal activity of the tested insecticidal alternatives against the Scymmus syriacus eggs in comparison with recommened insecticide:

Results represented in Table 1 illustrated that the insecticide; Nuvacron was the superior ovicidal against the eggs hatchability; where non hatching was noticed to the eggs laid by the Scymnus syriacus adult female. On the other hand, the compounds namely Caple-2 citric acid, profect were sure safer as an ovicidal action against the S.syriacus eggs hatchability. The corresponding eggs hatchability percentages were $18,80,51$ The other tested insecticidal alternatives occupied the middle situation among.

The ovicidal action against the $S$. Syriacus eggs agree are disagree with those recorded by Hurej and Ducher (1994). Generally, the tested compounds could be descendingly arranged in order to their ovicidal action as follows: nuvacron, CAPL-2, profect and citric acid the corresponding egg hatchability percentages were $0,18,51$ and 80 respectively. The egg hachability percentages in control were recorded $98 \%$.

Tale 1. Ovicidal effect of alternatives against egg of S.Syriacus

\begin{tabular}{|c|c|c|c|c|c|c|c|c|}
\hline \multirow{2}{*}{ Treatments } & \multicolumn{7}{|c|}{ Hatched of eggs after days } & \multirow{2}{*}{$\begin{array}{c}\text { Hatchability } \\
(\%)\end{array}$} \\
\hline & 1 & 2 & 3 & 4 & 5 & 6 & 7 & \\
\hline Profect & 3 & 11 & 7 & 4 & 9 & 9 & 9 & 51 \\
\hline Citric acid & 6 & 8 & 15 & 12 & 17 & 13 & 0 & 80 \\
\hline CAPL-2 & 3 & 5 & 3 & 4 & 2 & 1 & 0 & 18 \\
\hline Nuvacron & 0 & 0 & 0 & 0 & 0 & 0 & 18 & 0 \\
\hline Control & $\mathrm{N}$ & 16 & 14 & 15 & 13 & 11 & 18 & 98 \\
\hline
\end{tabular}

2. Effect of the insecticide atternatives as well as recommended insecticides on S.Syriocus larvae:

Results of the susceptibility of S.Syriacus larvae to the insecticide were evaluated. The obtained data are summarized in Table 2. Depending upon the larval mortality percentage of S.Syriacus, the biological activity tested insecticidal alternatives, as well as, the recommend insecticide could be dividel into for are groups as follows: the first group includes of insecticide the most effective on the S.Syriacus where the corresponding larval mortality was $88 \%$. The second group included Capl2 . the corresponding larval mortality percentages were $68 \%$. The third groud involved profect. The corresponding larval mortality rates were $24 \%$. The fourth one of the tested compounds exhibited the lowest efficiency against S.syriacus larvae. This group includes citric acid. The corresponding larval mortality rates were $70 \%$ (El-Sisi and Mousa, 2001). 
Table 2: Toxicity of the alternatives against larval stage of $S$. Syriacus.

\begin{tabular}{|c|c|c|c|c|c|c|c|c|c|c|c|}
\hline \multirow[t]{2}{*}{ Treatments } & \multicolumn{10}{|c|}{ Increase in mortalities after days } & \multirow{2}{*}{$\begin{array}{c}\text { Total } \\
\text { mortality } \\
(\%)\end{array}$} \\
\hline & 1 & 2 & 3 & 4 & 5 & 6 & 7 & 8 & 9 & 10 & \\
\hline Profect & 3 & 3 & 4 & 2 & 3 & 3 & 2 & 3 & 1 & - & 24 \\
\hline Citric acid & 1 & 1 & 1 & 2 & 2 & 1 & - & - & - & - & 70 \\
\hline Capl-2 & 13 & 19 & 19 & 15 & 2 & - & - & - & - & - & 68 \\
\hline Navacron & 19 & 17 & 27 & 23 & 2 & - & - & - & - & - & 88 \\
\hline Control & 0 & 0 & 1 & 1 & - & - & - & - & - & - & 2 \\
\hline
\end{tabular}

3-Effect of the insecticidal alternatives as well as the recommended insecticie the S.Syriacus pupae stage:

Results is Table 3 illustrated that the citric acid compound was the most safer for the S.Syriacus where the corresponding percent of pupae formation was $94 \%$. The most harmful predaceous insect $S$. Syriacus recorded where the rate of resulted pupae was $8 \%$. Generally, the product efficacy could be categorized into two group on the basis of their safety the resulted pupae were as follows; compounds named; frofect, citric acid were safer to predator pupae rates formation. The corresponding values of pupae formation were $74 \%$ and $94 \%$. Secondly compounds that exhibited high harmful to the metamorphosis of the predator to produce the pupae included CAPL-2 and nuvacron. The corresponding resulted pupae formation were 51 and $8 \%$. The metamorphosis of the predatory molting larvae to pupae in the untreated individuals was completed where the pupae rates recorded.

Table 3. Effect of the alternatives against pupae of the S.Syriacus

\begin{tabular}{|c|c|c|c|c|c|c|c|c|}
\hline \multirow[b]{2}{*}{ Treatments } & \multicolumn{7}{|c|}{ Increase in emergency after days } & \multirow{2}{*}{$\begin{array}{c}\text { Total } \\
\text { mortality } \\
(\%)\end{array}$} \\
\hline & 1 & 2 & 3 & 4 & 5 & 6 & 7 & \\
\hline Profect & 6 & 14 & 10 & 9 & 13 & 13 & 9 & 74 \\
\hline Citric acid & 5 & 11 & 18 & 15 & 18 & 16 & 11 & 94 \\
\hline CAPL-2 & 3 & 8 & 13 & 9 & 6 & 8 & 4 & 51 \\
\hline nuvacron & 2 & 3 & 2 & 1 & - & - & - & 8 \\
\hline Control & 7 & 12 & 16 & 18 & 14 & 13 & 19 & 99 \\
\hline
\end{tabular}

4-Effect of the the insecticidat alternatives as well as recommended insecticide on S.Syriacus adult stage.

The latent effects of the compounds used on the inhibition of the adult emergence are illustrated in Table 4. The results indicated that the CAPL-2, nuvacron had highly latent effect on the adult emergence, where the corresponding rates inhibition of the adult emergence, value were $79 \%$ and $84 \%$. On other hand, profect, and citric acid were safer and exhibited the lowest tatent effect on the predator. The corresponding inhibition of the adult emergence values were 15 and $5 \%$. While the adult emergence inhibition value in the untreated individuals was recorded $3 \%$. Similar results were obtained by Tomlin(1994) and Rizk et al.(1999). 
Table 4. Toxicity of the alternatives against adult stage of the S.Syriacus

\begin{tabular}{lcccccccccccc}
\hline Treatments & \multicolumn{1}{c}{ Increase in mortalities afterdays } & Inhibition \\
& \cline { 2 - 4 } & $\mathbf{1}$ & $\mathbf{2}$ & $\mathbf{3}$ & $\mathbf{4}$ & $\mathbf{5}$ & $\mathbf{6}$ & $\mathbf{7}$ & $\mathbf{8}$ & $\mathbf{9}$ & $\mathbf{1 0}$ & $\begin{array}{c}\text { of adult } \\
\text { emergence }\end{array}$ \\
\hline Profect & 1 & 1 & 1 & 2 & 4 & 1 & 2 & 2 & - & - & 15 \\
Citric acid & 0 & 1 & 1 & 1 & 1 & 1 & - & - & - & - & 5 \\
CAPL-2 & 18 & 20 & 21 & 11 & 9 & - & - & - & - & - & 79 \\
Nuvacron & 20 & 26 & 20 & 18 & - & - & - & - & - & - & 84 \\
Control & 0 & 1 & 1 & 1 & - & - & - & - & - & - & 3 \\
\hline
\end{tabular}

As conclusion for results shown in Tables 1, 2, 3 and 4 mentioned that the conventional insecticide nuvacron was the most hazardous treatment against the natural enemy stage while all tested alternatives showed less hazardous effect, citric acid was the most safely material against. S. Syriacus followed by tested biocide and CAPL-2 therefore, these material achieve more safely for the natural enemy of aphid. S.Syriacus are preferred for controlling such pests for their conservation of the natural enemy, which are considered as an important element for controlling the pest.

Generally, in this field of study, many investigators explained the mode of action of the tested materials effect on immature and adult stages of S. Syriacus.

Conclusively, it could be concluded that the safe and cheep alternatives are preferred for controlling pests than conventional pesticides for their low hazardous effect against the natural enemy $S$. Syriacus citric acid was the most safe material followed by tested biocide and mineral oil it is intereted to note that the efficiency of the tested compundes should be evaluated against the pest in the objective of concluding whether their role in the (IPM) programs are on the basis of there effects on both natural enemies and the pests.

\section{REFFERENCES}

Ahmed M.K. (1995). Comparative effect of systox and scharadam on some predators of aphids in Egypt. J. Econ. Entomol., 48: 530-532.

Barlett, B.R. (1964). The toxicity of some pesticides to eggs, larvae and adult of the green lacewing Chaysopa carnea. J. Econ. Entomol., 57: 366-374.

El-Hariry, M.A.; A. Marzouk; R.M. Salem; E.M.E. Kallafalla and A. G. El-Sisi (1998). Field and laboratory evaluation of environmental safe chemicals against some aphid species, Egypt. Agric. Res., 76 (1): 127-139.

El-Sisi A.G. and G.M. Mousa (2001). Pesticidal of some inorganic salts against sucking pests imfested Phaseolous vulgar is seedling. Egyptain J. Agric., 19 (3): $835-845$.

Hure, M. and J.D. Dutcher (1994). Indirect effect of insecticides used in ecan orchards to Thrysoperal rufilabris. J. Entomol. Sci., 29: 450-456. 
Mousa G.M. and A.G. El-Sisi (2001). Testing of some local alternatives: mineral oil, plant material and surfactant against piercing and sucking pests infesting squash crop. Safe. Alternative for Pest Management Conf. Assiut Univ., 83-90.

Rizk M.A.; A.G. El-Sisi, N.A. Badr and S.M. Abdel-Haleem (1999). Controlling of cotton sucking pests using safe materials. $2^{\text {nd }}$ Int. Conf. of Pest Control, Mansoura, 211-221.

Tomlin, C. (1994). The Pesticide Manual. Incorporating the Agrochemical Handbook. $10^{\text {th }}$ ed., The Roval society at chemistry crop protection publications pp.1341.

Topper C.; G. Moawad; D.Maxmley; M. Hosny; K .Jones; J. Copers; S. ElNagar; M. El-Sheik; E.L. Nagar and M.El. Shik (1984). Field trals with a nuclear polyhedrosis virus against Spodopter littoralis on cotton in Egypt. Tropical. Pest, Management, 30(4): 372-378; 14 ref.

Zhao, Huaqi; Miao, Chunsheng; Sun Yu Ying; Gao. Yufan; Zhao, H.Q. Miao; C.S. Sun and Y.Y. Gaoyf (1995). Research on the control of bollworms resistant to pesticide with B.T. var. Kenyae emiulsion China, Cottons, 22 (7): 15-16, 3ref.

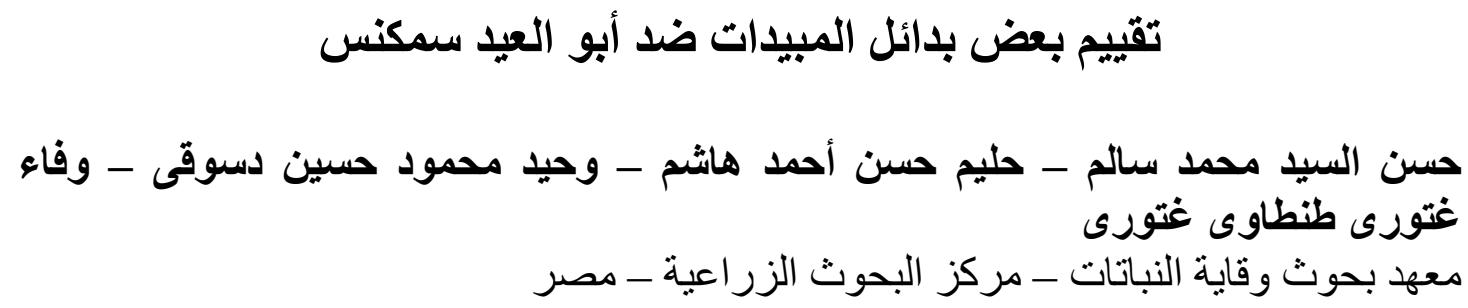

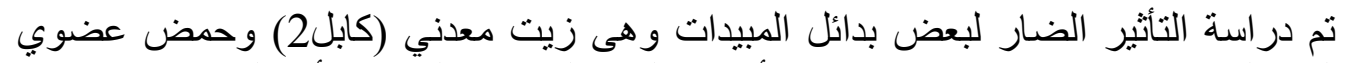
(حمض الستريك) ومبيد حيوى (بروفكت) ، ضد أطوار العدو المفترس الحشري أبو العيد سمكنس وهو لهون

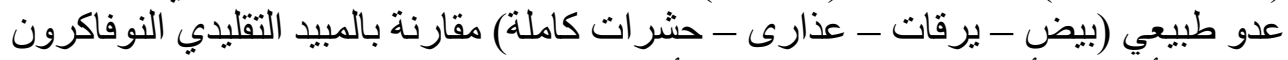

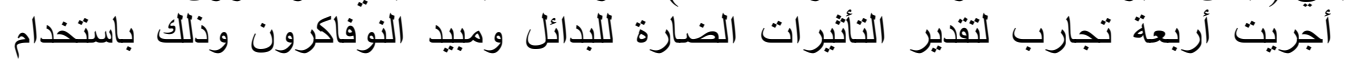
الجر عة الموصى بها لمكافحة المن. التجربة الأولى: لتقدير التأثير المثبط لفقس البيض والثانية: لتقدير التأثثير السام ضد الطور

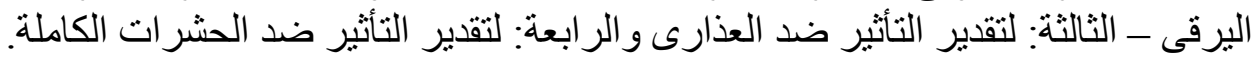

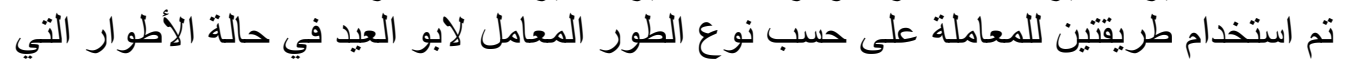

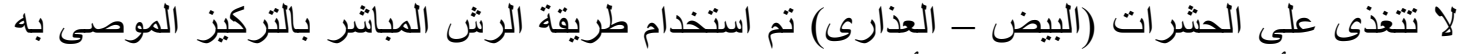

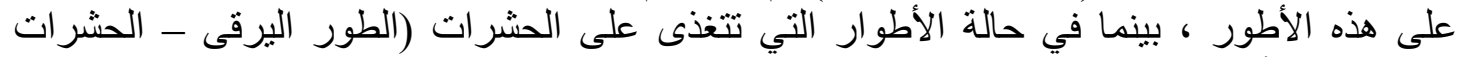

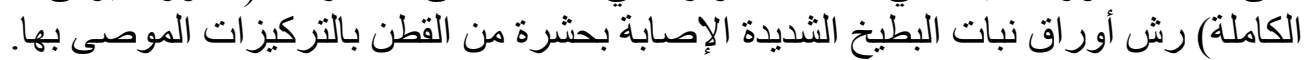

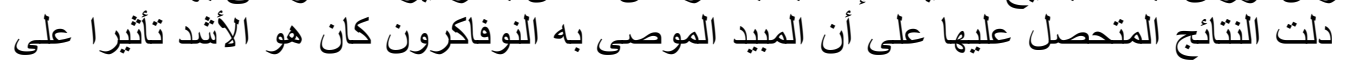

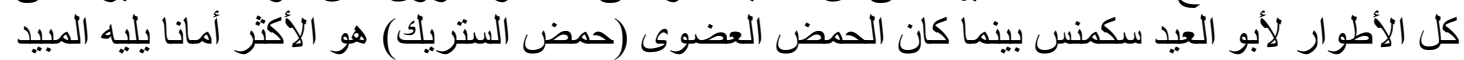

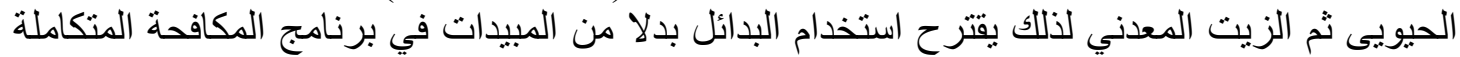

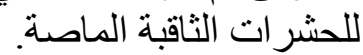

